See discussions, stats, and author profiles for this publication at: https://www.researchgate.net/publication/325539944

\title{
The influence of instructional on writing based on context toward reading
} interest

Conference Paper · January 2018

DOI: $10.29210 / 2018124$

CITATIONS

3 authors, including:

Atmazaki Atmazak

Situs Resmi Universitas Negeri Padang

15 PUBLICATIONS 8 CITATIONS

SEE PROFILE
READS

Some of the authors of this publication are also working on these related projects:

The development of digital-based authentic assessment in Indonesian Language View project 


\title{
The influence of instructional on writing based on context toward reading interest
}

\author{
Riza Nusahak ${ }^{1}$, Atmazaki ${ }^{2}$, Abdurahman $^{3}$ \\ ${ }^{123}$ Universitas Negeri Padang, Padang - Indonesia, (nusahak.riza@gmail.com)
}

\begin{abstract}
Quasi experimental research with $2 \times 2$ factorial was designed to describe the influence of method-based context toward reading interest in writing skills. It was assumed that reading interest played an important role in writing and based approaches context would make it easier for students to produce their writing. The results shown that generally there were differences on students' writing product outcomesat SMKN-2 Sawahlunto with CTL (experiment) and conventional approaches (control), both that had high or low reading interest. In addition, there was a connection between approaches in learning and reading interest on students' success in writing exposition text. CTL approach affected high writing skill and reading interest. It is suggested that students' interest in reading is a concern to support writing exposition text.
\end{abstract}

Keywords: CTL, reading interest, writing exposition text

\section{Introduction}

There are several problems found in instructional of writing exposition text. Students were not insterested to write. Their motivation in writing was low. Futhermore, developing ideas, finding approprate model and media, choosing the right strategy in writing were difficult for them. Aji (2015: 2) and Junedi (2016:5) said that these problems trigged by many factors. Bloom and Piaget (in Rahim, 2011: 20) explain that understanding, interpretation, and assimilation are the dimensions of the cognitive hierarchy. However, all these cognitive aspects come from affective aspects such as interest, confidence, and control of negative feelings, and delay and willingness to take risks. In addition, the learning environment, the media, and the approach that teachers use also have an impact on students' writing skills.

Syamsi (2012: 1), Trimantara (2005: 1), Arini (2012: 66), Rahayu, Sri, I. W. Rasna, and G. Artaawan. (2013: 1), Mundziroh, Siti, Andayani, and KundharuSaddhono. (2013: 1), Rohaeti (2012: 1), Maryani, Marhaeni, and M. Sutama. (2013: 1), Ulfa, Maria, Amir Fuady and NugraheniEkoWardani (2013: 1), Anggrayani, Ni Made Mita, ImadeSutama, and IgedeNurjaya (2016: 1), Milawati (2011: 70) mentioned about learning tools based on the genre process by using imaginative suggestion method, mind-map method of direct 
object-oriented, contextual method, picture and picture method, collaborative technique, mind mapping strategy, peer-correction technique, modeling technique, and SAVI model that was proven to have a positive impact on the writing process. Similarly, Kosasih (2017: 109) stated that teacher-based learning or training model could be more effective and more systematic for learning because they didthe process directly based on the problems and real needs faced in the field.

Thus, this study was focused on four points. (1) Reading interest.Zurina (2013: 160) reading interest is important to improve the success of students at school and outside school. In line with previous opinion Janah (2014: 3) states that the skills of writing expository texts can be obtained from reading. The number of readings read is influenced by reading interest. (2) CTL approach. Nurhadi (2004: 4) stated that CTL approach is a unit of learning concept, the teacher presents real-world situations into the classroom and encourages students to make connections between their knowledge and application in life as family members and society. (3) Exposition text. Semi (2003: 35), the exposition is an essay that gives an explanation of things, events or events. The third thing is what makes this research different from previous research. CTL approach was used as a treatment in writing expository text that is moderated by reading interest and performed at SMKN 2 Sawahlunto. (4) SMKN 2 Sawahlunto was chosen because the majority of students were male and reading interest was also influenced by sex.

Therefore, the purposes of this research were to describe the difference of learning result of writing expository text that was taught by using CTL approach with students who was taught by using conventional approach at X grade of SMKN 2 Sawahlunto, to describe the difference of learning result of writing expositionstext of students interested in reading high taught using CTL approach with high reading students taught using conventional approach in students of $X$ grade SMKN 2 Sawahlunto, to describe the difference of learning result in writing expositions text of students who has low reading interest at $X$ grade of SMKN 2 Sawahlunto, to describe the interaction between the CTL approach and reading interest in writing expository text $X$ grade of SMKN 2 Sawahlunto.

\section{Method}

This research was a quasi-experimental research that used factorial design 2x2(Sugiyono, 2010: 11 )andSugiyono, 2015: 113). This research was conducted in SMKN 2 Sawahlunto. The populations were the students of $X$ grade at SMKN 2 Sawahluntoin 2016/2017academic year.Purposive sampling technique was used to get experiment class(33 students) and control class (34 students). This research had three variables, they were dependent variable (expository writing skill and moderator (interest reading), and independent variable (CTL approach).So, there are two types of research data, namely reading score of students' reading interest that was obtained from questionnaire and the score of students' exposition writing skill was obtained from performance writing test of expository text. These data were obtained by systematic research procedure that could be seen in the following chart 1. 


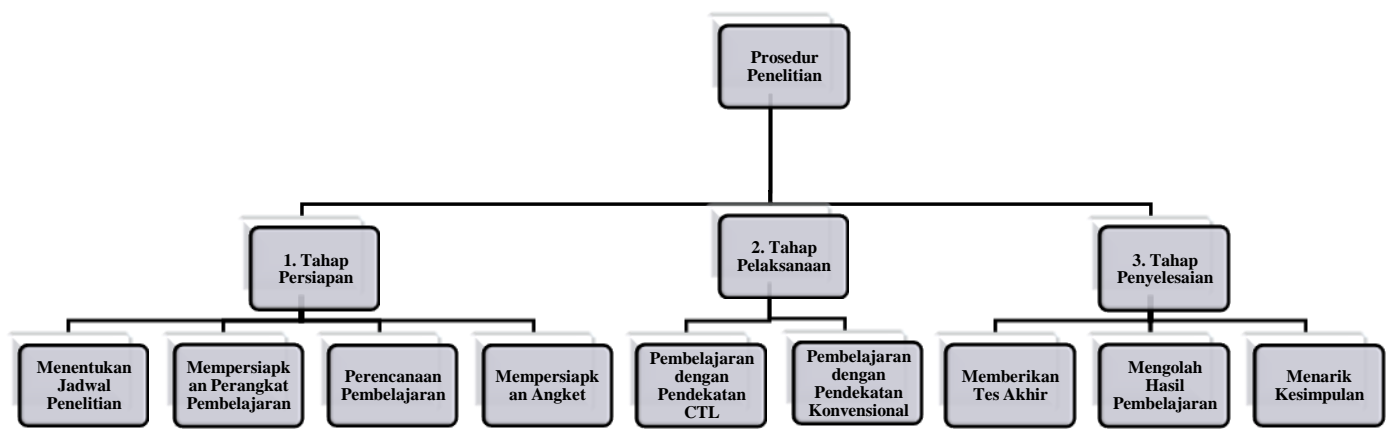

Picture 1 chart of research procedure

The data were analyze by reading, identifying, scoring, summing scores, parsing, and classifying high-reading students by attracting $27 \%$ of each group (Allen and Yen in Kumaidi, 1994: 9). While the results of students' performance tests were analyzed by reading, identifying, scoring, converting scores into values by equation formulas, transforming values to scale 10 (Nurgiyantoro in Abdurahman and Elia Ratna, 2003: 264). Furthermore, the data were analyzed by using statistical method, data normality test (Lilliefors), homogeneity test data (F test), hypothesis test ( $\mathrm{t}$ test and ANAVA) (Sudjana, 2005: 249 and Riduwan, 2011: 185).

\section{Results and Discussion}

The results will be described in Table 1Tabel

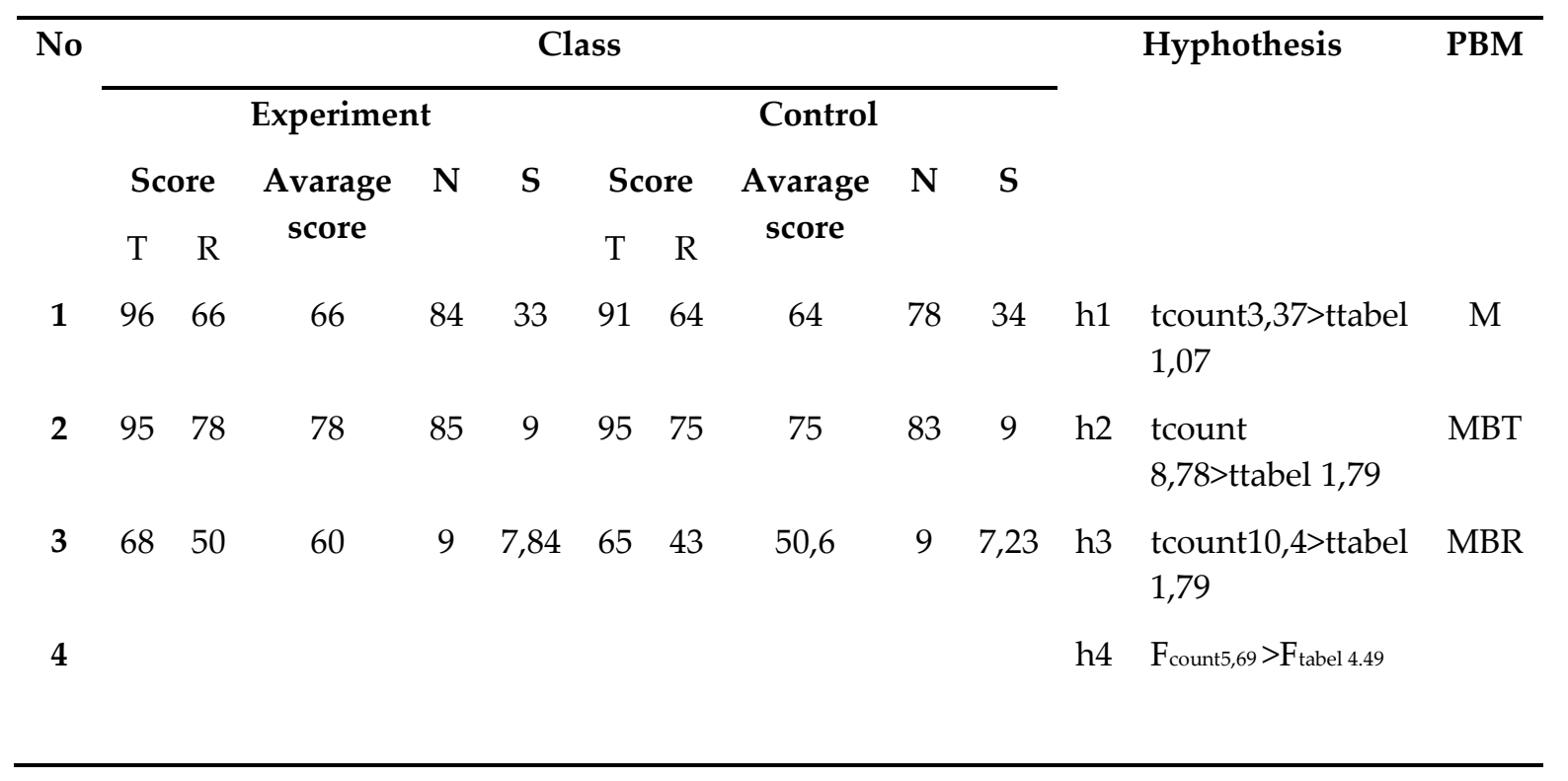

Note:

Q : Top rated

$\mathrm{R} \quad$ : Lowest Value 


$\begin{array}{ll}\text { N } & \text { : Number of Students } \\ \text { S } & \text { : Standard Deviation } \\ \text { M } & \text { : Writing } \\ \text { MBT } & \text { : Write High Readiness Read } \\ \text { MBR } & \text { : Writing Low Read Interest }\end{array}$

Table 1 shown that there were differences in learning outcomes in writing expositions text of students who were taught by using CTL approach with students who were taught by using conventional approach at X grade SMKN 2 Sawahlunto. Aaron (2010: 70) states that CTL learning approach results in better mathematics learning achievement. In addition Andarani et al (2013: 1) stated that there was influence of CTL learning approach through flipchart media with video on learning achievement. Ariasta (2013:1) stated that the CTL approach to the GI method results in better chemistry learning achievements. Furthermore, Widiyarto (2017: 1) "there were significant interest in reading and mastery of vocabulary jointly affect the writing skills exposition.

The use of CTL gave students the opportunity to discover the meaning and meaning of themselves in learning, and relating it to everyday life (Johnson, 2011: 301). Implementation of teaching and learning CTL allowed students to work alone and construct their own new knowledge and skills (Rusman, 2010: 192).

The data found about the reading interest that moderate students' writing skills turned out to have an impact on student learning outcomes SMKN 2 Sawahlunto. Janah (2014: 3) stated that the skills of writing expository texts could be obtained from reading. The number of readings read was influenced by reading interest. Previously Zurina (2013: 160) suggested reading interest was important to improve the success of students at school and outside school.

The impact of reading interest was shown by the result of learning skill of writing class at X garde of SMKN 2 Sawahlunto who taughtby using CTL approach. This caused students to use various vocabulary and able to think critically. Aceng (2016: 157) said that critical thinking skills and contextual learning models had a significant influence on argumentative writing skills not only forstudents who couldwrite based on the experience honestly. Richard (1981: 221) stated that Effective writing requires personal experience, honesty, and experience.

Thus, it could be concluded that either overall or even based on high reading interest there was a difference in learning outcomes in writing exposition text of students who were taught by using CTL approach with students who were taught by using conventional approach in students of class X SMKN 2 Sawahlunto.

This study also shown that there was relationship between CTL approach and reading interest towards the skill of writing expository text of Xgrade students at SMKN 2 Sawahlunto. Apparently the CTL approach had a positive effect on students who had high reading interest. This was also triggered by the individual nature of the student. Stepehn (2016: 1) individuals who had high reading interest were more intellectual, while students who are more interested in reading news, sports, and romance or sexuality were more conventional. Judging from the condition / state of the student's psyche, reading interest tends to be influenced by the state of the student's soul, whether in a happy, sad, or restless state. This feeling that sometimes triggers the low interest in reading students. Soeatminah (1991: 73-75) points out that if a person (especially children) who has an 
interest in reading is in a state of restlessness, sad or confused, most people if in such circumstances his passion for reading will decrease / may disappear. Different if in a happy / happy state that person will be very eager to read.

Problems of low interest students could be overcome by increasing reading interest first. It could be done by using Glenn Doman method and kinesthetic learning style that has been proven to increase students' reading interest (Ahmad, 2017: 1 and Abduraby, 2014: 2). Not only from the students, should increasing students' reading insterest also be done on teachers. Barbaran (2013: 1) teacher's enthusiasm for reading had a considerable influence on reading interest and students' reading ability.Another step that could be done was to choose the right treatments to improve the learning outcomes of Syamsi students (2012: 1), Trimantara (2005: 1), Arini (2012: 66), Rahayu, Sri, I. W. Rasna, and G. Artaawan. (2013: 1), Mundziroh, Siti, Andayani, and KundharuSaddhono. (2013: 1), Rohaeti (2012: 1), Maryani, Marhaeni, and M. Sutama. (2013: 1), Ulfa, Maria, Amir Fuady and NugraheniEkoWardani (2013: 1), Anggrayani, Ni Made Mita, ImadeSutama, and IgedeNurjaya (2016: 1), Milawati (2011: 70) mentioned learning tools based on genre process, using imaginative suggestion method, direct object minded, mind map method, contextual method, picture and picture method, collaboration technique, mind mapping strategy, peer-correction technique, modeling technique, and SAVI model.

Thus, when there was influence of CTL approach and reading interest toward students' ability in writing expository text. It was necessary to select appropriate approaches, methods, models, strategies, and techniques in writing expository texts.

\section{Conclusion}

Based on the results and discussion of this study, it can be concluded as follows. (1) There was difference ofstudents' learning achievementin writing exposition text taught using CTL approach andstudent taught using conventional approach at $\mathrm{X}$ grade at SMKN 2 Sawahlunto. (2) There was difference writing of result of expositional text of students who had high reading interest by using CTL approach and conventional approach at $\mathrm{X}$ grade at SMKN 2 Sawahlunto. (3) There was difference of writing result of expositional text of students who had low readinginterest by using CTL approach and conventional approach at $\mathrm{X}$ grade at SMKN 2 Sawahlunto(4) There was learning interaction between CTL approach and reading interest toward the expository writing skill of $X$ grade students of SMKN 2 Sawahlunto.

Due to the interaction in learning, it is suggested to pay attention on the students' reading interest and further effort to increase students' reading interest. This can be done by facilitating good reading for students and good media of reading to foster students' interest in reading. Teachers can also look for alternative approaches, such as using the Discovery Learning Model.

This article was written as one of the requirements to meet some requirements to obtain Master of Education degree in Indonesia Language and Literature Education Program, State University of Padang. Therefore, thanks go to the mentors and contributors of the thesis who have helped to provide criticism, suggestions, or feedback. Furthermore, thanks go to reviewers who have read, corrected, and provided input this research article. 


\section{References}

Abdurahman \& Elia Ratna. (2003). Evaluasi pembelajaran bahasa dan sastra Indonesia. Bahan Ajar. Padang: UNP.

Aceng, H. (2016). Enhancing argumentative writing skill through contextual teaching and learning. Jurnal ERIC. Vol 11 no 16 p 1573-1578.

Ahmad, F. (2017). Meningkatkan minat membaca siswa sekolah dasar dengan metode glenndoman berbasis multimedia. Jurnal Penelitian Pendidikan. Volume 27. Nomor 1.

Aji, A. R. B. (2015). Peningkatan keterampilan menulis eksposisi melalui Model pembelajaran member dan menerima pada siswa kelas VII E SMP Negeri 5 Wates Kabupaten Kulon Progo DIY Skripsi. Yogyakarta: Universitas Negeri Yogyakarta.

Alduraby, H. (2014). "Using the branching story approach to motivate students' Interest in reading." International Electronic Journal of Elementary Education, 6(3), 463-478.

Andarini, t. M Masykuri \& Suciati Sudarisman. (2013) “Pembelajaran Biologi menggunakan pendekatan CTL (Contextual Teaching and Learning) melalui media flipchart dan video ditinjau dari kemampuan verbal dan gaya belajar." Jurnal Bioedukasi. Volume 6. Nomor 2. Halaman 102-119.

Anggrayani, Ni M, Imade Sutama, \& Igede Nurjaya. (2015). “ Penerapan Teknik pemodelan dalam pembelajaran menulis cerpen pada siswa kelas VII K SMP Negeri 1 Negara." E jurnal Pendidikan Bahasa dan Sastra Indonesia Universitas Pendidikan Ganesha. Vol 5 No 3.

Arini, N W. (2012). “Implementasi metode peta pikiran berbantuan objek langsung untuk meningkatkan keterampilan menulis deskripsi." Jurnal Pendidikandan Pengajaran. Jilid 45 No 1 hal 66-74.

Barbaran, JC. (2013). Evaluating the relationship between tacher credential student's ability to read and thire interest reading. Dissertation. California: Univercity Nolth Central.

Janah, N. M. (2014). Hubungan minat baca dan penguasaan kosakata dengan kemampuan menulis teks eksposisi pada Siswa kelas X SMA Negeri Sekabupaten Bantul. Skripsi. Yogyakarta: Universitas Negeri Yogyakarta.

Johnson, E B. (2011). CTL (Contextual Teaching and Learning). Bandung: Kaifa.

Kosasih, E. (2017) "Efektifitas penerapan model pembelajaran berbasis proyek dalam pengembangan kualifikasi akademik dan kompetensi guru." Lingua XIII (2).

Kumaidi. (1994). Studi analitik terhadap karakteristik internal dari ujian seleksi masuk keperguruan tinggi. Makalah. Jakarta :Balitbang

Maryani, N. W, A. A. I. N Marhaeni, dan M. Sutama. (2013). “Pengaruh Implementasi strategi Mind Mapping terhadap prestasi belajar menulis kreatif ditinjau dari kreativitas siswa." E Jurnal Program Pascasarjana Universitas Pendidikan Ganesha Jurusan Pendidikan Dasar. Vol 3.

Milawati, T (2011). Peningkatan kemampuan anak memahami drama dan menulis teks drama melalui model pembelajaran somatic auditori visual intelektual (SAVI). Jurnal edisi khusus. No. 2.

Nurhadi. (2004). Pendekatan contactual (contactual teaching and learning). Jakarta: Departemen Pendidikan Nasional.

Rahayau, S, I. W. Rasna, dan G. Artaawan. (2013). "Penerapan model Pembelajaran kontekstual dalam pembelajaran menulis pada siswa kelas XII SMKN 1 Denpasar." 
E Jurnal Program PascasarjanaGanesha Program Studi Pendidikan Bahasa dan Sastra Indonesia. Vol 2.

Rahim, F. (2008). Pengajaran membaca di sekolahdasar. Jakarta: BumiAksara.

Rohaeti,I.(2012). "Model pembelajaran teks berita dengan menggunakan Teknik kolaborasi pada siswa kelas VIII SMP Negeri 1 Kadungora KabupatenGarut." Bandung: STKIP Siliwangi.

Richard, M. (1981). Teaching exspositori writing. Jurnal ERIC.

Riduwan. (2011). Dasar-dasar statistika. Bandung: Alfabeta.

Rusman. (2010). Model-model pembelajaran mengembangkan profesional Guru. Jakarta: Raja Grafindo.

Semi, A. (2003). Menulis efektif. Padang: Angkasa Raya.

Stepehn J, D. (2016). "You're ask you read': do student's reading interest contribut to theire individuality?. Jurnal International Education Studies. Vol 37 no 1 p 1-26.

Sudjana. (3005). Metodestastitika. Bandung: Tarsito.

Sugiyono. (2010). Metode penelitian pendidikan. Bandung: Alfabeta.

Sugiyono. (2015). Metode penelitian pendidikan pendekatan kuantitatif, kualitatif, dan RED. Bandung: Alfabeta.

Syamsi, K. (2012). "Model perangkat pembelajaran menulis berdasarkan Pendekatanproses genre bagi siswa siswa SMP". Jurnal Penelitian Bahasa, Sastra, dan Pembelajaranya. Vol 11 No 2.

Trimantara, P. (2005). "Metode sugesti imajinasi dalam pembelajaran menulis denganmedia lagu." Jurnal Pendidikan Penabur. Vol 1. No 05.

Ulfa, M, Amir Fuady, dan Nugraheni Eko Wardani. (2013). “Teknik Peer-Corrction untukmeningkatkan kualitas proses dan hasil pembelajaran menulis karya ilmiah siswa sekolah menengah atas. "Penelitian Bahasa Sastra Indonesia dan Pengajaran. Vol 2 No 1.

Widiyarto, S. (2017) "Pengaruh minat baca dan penguasaan kosakata terhadap keterampilan menulis eksposisi." Jurnal Pesona. Vol 1 No 3 halaman 74-80.

Zurina, K. (2013). A Study of student's reading interest in a second language. Jurnal International Education Studies. Vol 6 no 11 p 160-170. 